\title{
Antibacterial force of the luting-type of glass ionomer cement toward Lactobacillus species and Streptococcus mutans
}

\author{
Dwi Warna Aju Fatmawati and Ekiyantini Widyowati \\ The Conservation Division of Dental Hospital \\ The Faculty of Dentistry, The University of Jember \\ Jember - Indonesia
}

\begin{abstract}
Rigid restoration is attached within oral cavity using adhesive cement layer. The hardening adhesive cement fills and tights the rough tooth surface with reciprocal opposing restorations. The luting type of glass ionomer cement was mostly used in the clinic for crown cementation as well as poured restoration. We can be taken a problem how strong is antibacterial effect of the luting type of glass ionomer cement to Lactobacillus species and Streptococcus Mutans. The purpose of the research was to know the antibacterial force of the luting-type of glass ionomer cement toward Lactobacillus species and Streptococcus mutans. This research was a laboratory experiment. The samples of the research were divided into two groups, treated-group (Fuji and Shofu) and controlled-group. The numbers of samples in each group consisted of 7 pieces. Taking 0,5 $\mathrm{ml}$ of artificial saliva in which the sample of the luting-type of glass ionomer cement ( $5 \mathrm{~mm}$ in diameter and $2 \mathrm{~mm}$ thick) had been immersed and storing it into Petri dish containing warm MRSA and $0,1 \mathrm{ml}$ Lactobacillus sp. using poured technique. The mixture was subsequently incubated, and the colony was counted on the observation of $1^{\text {st }}$ day, $7^{\text {th }}$ day, and $14^{\text {th }}$ day. The data were analyzed using ANOVA and LSD. The result of the research showed that the greatest mean value of the bacterial colony presented in the controlled-group and the smallest was in the group of Shofu. Statistical analysis showed a significant difference $(p<0.05)$. The released fluoride from glass ionomer cement occurred in the damaging phase caused by polyacrylate that released $\mathrm{H}^{+}$ion from carboxyl group $(\mathrm{COOH})$. The fluoride influenced the growth of bacteria by decelerating the activity of gycolytic enolase enzyme. The luting-type of glass ionomer cement had antibacterial force toward Streptococcus mutans and Lactobacillus sp. The luting-type of glass ionomer cement of Shofu possessed greater antibacterial force than Fuji and controlledgroup.
\end{abstract}

Key words: antibacterial force, luting-type of glass ionomer cement, Lactobacillus sp, Streptococcus mutans

Correspondence: Dwi Warna Aju Fatmawati, The Conservation Division of Dental Hospital the Faculty of Dentistry, The University of Jember. Jln. Kalimantan 37 Kampus Tegal Boto Jember, Indonesia. E-mail: warna_ayu@ yahoo.co.id. Telp. 0331-333536.

\section{INTRODUCTION}

Rigid restoration is attached within oral cavity using thin-layered adhesive cement. The hardening adhesive cement fills and tights the rough tooth surface with reciprocal opposing restorations. Adhesive cement is used to prevent edge leaking, and the cement layer should be made as thin as possible (approximately $80 \mathrm{um}$ ) so that it is not soluble within saliva. ${ }^{1}$ This hardening material not only covers the space but also retains the restoration. The material used in this requirement is classified as the type 1 cement. $^{2}$ In the last two decades, adhesive cement has been developed into adhesive attachment and possessed therapeutic effects such as glass ionomer cement. ${ }^{3}$

Glass ionomer cement was initially used by Wilson and Kent in 1971. The luting type of glass ionomer cement was mostly used in the clinic for crown cementation as well as poured restoration. ${ }^{4}$ The main advantage of this cement is its adhesive force upon dentin and email. According to Subiyanto, ${ }^{5}$ this material performed chemical binding between atoms or molecules from the material and enamel or dentin resulting in stronger ion bindings or covalence bindings compared to physical binding This cement is also adhesive on the surface oxidized from alloy used for metalceramic restoration and upon the surface of tin-layered gold restoration ${ }^{1}$. This material functions to fill the roughness on the preparation and crown surface or pouring to provide mechanical attachment on the rough surface and result in an excellent restoration. ${ }^{6}$

Subiyanto $^{5}$ stated that fluoride ion consisted in ionomer cement was the effort to obtain anticariogenic and antibacterial traits. $\mathrm{Craig}^{7}$ and Summit $^{8}$ said that there was no improvement in the number of bacteria during 56 days after crown cementation using glass ionomer cement. It was because the height of fluoride ion degree released from the glass ionomer cement. The most essential antibacterial effect of fluoride was disturbing the metabolism of bacteria. $^{5}$

Budi $^{9}$ said that the main reason of restoration failure was caused by secondary caries. Streptococcus mutans had important roles on the carries occurrence, or the restoration failure caused by very acidogenic Streptococcus mutans which rapidly produced acid leading to the demineralization of apatite hydroxide.

Lactobacillus species is often called as predominant micro-flora within the lesion of deep dentine caries. It has 
made Lactobacillus species stated as the influential factor in the caries. ${ }^{10}$ Ford ${ }^{1}$ said that Lactobacillus species was the bacteria mostly found along dentine tube. It indicated that the ability of Lactobacillus species to survive in the acid circumstance was as well as their ability to form acid itself. Meanwhile, the number of bacteria within plaque on the tooth surface was very small and caused no email caries, however, it involved in damaging dentin.

Based on above elaboration, can be taken a problem how strong is antibacterial effect of the luting type of glass ionomer cement to Lactobacillus species and Streptococcus mutans. This research was aimed at knowing the antibacterial force of the luting-type of glass ionomer cement toward Lactobacillus species and Streptococcus mutans. The result of the research was expected to be advantageous not only to the development of dental material science of restoration but also to used for everyone who has competence in dental conservation.

\section{MATERIAL AND METHOD}

This research was a laboratory experiment. The method used in this research was post-test only control group design. The objects of the research were divided into two groups, treated-group (Fuji and Shofu) and controlled-group. All of the instruments and materials used in the research were firstly sterilized in an autoclave within temperature of $121^{\circ} \mathrm{C}$ for 30 minutes.

The procedure of making suspension of Streptococcus mutans was conducted by planting the culture in a reacting tube containing $5 \mathrm{ml}$ sterile Tripticase Soy Broth (TSB) unaerobically, and storing it in an incubator with temperature of $37{ }^{\circ} \mathrm{C}$ for 24 hours and subsequently followed by taking 1 cc Streptococcus mutans from TSB using a disposable syringe, diluting it as many as $10^{-7}$. Similar procedure was also carried out to make suspension of Lactobacillus sp, however, it used manitol rogosa sharpe broth (MRSB) as the medium.

The procedure of making sample (Fuji and Shofu) was through measuring the powder and the luting-type of glass ionomer cement according to the instruction of the manufacturer and mixing them to be a homogenous mixture and its consistence could be lifted and not cut off as high as $\pm 1 / 2-3 / 4$ inch, and storing in a brass plate cast with $5 \mathrm{~mm}$ in diameter and $2 \mathrm{~mm}$ thick and let it to setting (for 5 minutes). After setting, the sample was immersed in artificial saliva. Only the controlled-group that used artificial saliva. The sample was then incubated in an incubator with temperature of $37^{\circ} \mathrm{C}$ for 1 day, 7 days, and 14 days.

The treatment procedure was carried out by taking $0,5 \mathrm{ml}$ of sterile artificial saliva (containing immersed sample of the luting-type of glass ionomer cement (Fuji and Shofu brands)) and putting it in a sterile Petridish. Afterward, the saliva was added by $0.1 \mathrm{ml}$ of Streptococcus mutans and warm $25 \mathrm{ml}$ tripticase soy agar (TSA). On the other Petridish (poured plate technique), $0.5 \mathrm{ml}$ of artificial saliva was mixed with $0.1 \mathrm{ml}$ of Lactobacillus sp. and $25 \mathrm{ml}$ manitol rogosa sharpe agar (MRSA). The mixture was then stirred by spinning the Petridish (poured plate techniqu) to be homogenous mixture. After TSA and MRSA media were hard, they were stored in the decisator with reversed position of Petri dish and incubated in an incubator with temperature of $37^{\circ} \mathrm{C}$ for 24 hours. Observation was conducted on the $1^{\text {st }}$ day, $7^{\text {th }}$ day, and $14^{\text {th }}$ day. The colony number was counted using a colony counter. The counting result of the Streptococcus mutans colony was in the entity of colony forming unit (cfu) per milliliter. ${ }^{11}$

Streptococcus mutans and Lactobacillus sp were counted three times using a colony counter to obtain the mean. The counting results of Streptococcus mutans and Lactobacillus $s p$ were in the entity of cfu per milliliter. ${ }^{11}$

The data were analyzed using One-Way ANOVA statistic test, and further differences of both materials used were analyzed using multiple comparison test by Least Significant Difference (LSD).

\section{RESULT}

Table 1 showed that on the observation of the $1^{\text {st }}$ day, $7^{\text {th }}$ day, and $14^{\text {th }}$ day, the mean of the number of Lactobacillus $s p$ in the controlled-group was greater compared to Shofu and Fuji. Meanwhile, the mean of least number of Lactobacillus $s p$ was found in Shofu.

Table 1. Mean and deviation standard of the number of Lactobacillus sp colony in the observation on the $1^{\text {st }}$ day, $7^{\text {th }}$ day, and $14^{\text {th }}$ day

\begin{tabular}{|c|c|c|c|c|c|c|}
\hline \multirow{3}{*}{ Samples } & \multicolumn{6}{|c|}{ The number of Lactobacillus sp. (cfu/ml) } \\
\hline & \multicolumn{2}{|c|}{1} & \multicolumn{2}{|c|}{7} & \multicolumn{2}{|c|}{14} \\
\hline & Mean & DS & Mean & DS & Mean & DS \\
\hline Controlled & 380.71 & 6.87 & 380.86 & 6.01 & 381.57 & 6.85 \\
\hline Shofu & 183.57 & 4.93 & 286.57 & 4.72 & 324.86 & 4.30 \\
\hline Fuji & 268.29 & 2.56 & 313.29 & 5.28 & 349.29 & 4.31 \\
\hline
\end{tabular}


Table 2. The result of One-Way ANOVA test toward the number of Lactobacillus sp colony

\begin{tabular}{llrl}
\hline & & df & Sig. \\
\hline $1^{\text {st }}$ Day & Between Groups & 2 & .000 \\
& Within Groups & 18 & \\
& Total & 20 & \\
$7^{\text {th }}$ Day & Between Groups & 2 & .000 \\
& Within Groups & 18 & \\
& Total & 20 & \\
$14^{\text {th }}$ Day & Between Groups & 2 & .000 \\
& Within Groups & 18 & \\
& Total & 20 & \\
\hline
\end{tabular}

The result of the normality and homogeneity test found that the significant value was greater than $p>0.05$, it meant that the data of analyses obtained in each variable were normal homogeneity. The subsequent test was One-Way ANOVA test and LSD with significant level $\mathrm{p}<0.05$. This is showed in the table 2 and 3.

In the table 2, the result of ANOVA test showed that the significant value of antibacterial test of the luting-type of glass ionomer cement toward Lactobacillus sp was $p<0.05$. The result of LSD test showed that there was a significant difference between the controlled-group and the treated-group.
Table 4 showed that in the observation of $1^{\text {st }}$ day, $7^{\text {th }}$ day and $14^{\text {th }}$ day, the mean of colony number of the Streptococcus in the controlled-group was greater than treated-group. Meanwhile, the least number was found in Shofu group.

The result normality and homogeneity test showed that significant value was greater than $\mathrm{p}>0.05$, it meant that the data of analyses obtained in each variable were normal homogeny. The One-Way ANOVA test and LSD showed the significant level $\mathrm{P}<0,05$ as showed in table 5 and 6 .

In the table 5, the result of ANOVA test showed that the significant value of antibacterial force of the lutingtype of glass ionomer cement toward Lactobacillus $s p$ was $\mathrm{p}<0.05$. The LSD test (Table 6) showed that there was a significant difference between the controlled-group and the treated-group.

\section{DISCUSSION}

The result of the research showed that mean value of antibacterial force of the luting-type of glass ionomer cement toward Lactobacillus sp and Streptococcus mutans was higher than treated-group, while glass ionomer cement of Shofu had greater antibacterial force than glass ionomer cement of Fuji. Analytical test showed that there was significant difference. It was because the powder

Table 3. The result of LSD test toward Lactobacillus sp colony

\begin{tabular}{|c|c|c|c|c|}
\hline & \multirow[t]{2}{*}{ (I) } & \multicolumn{3}{|c|}{ (J) } \\
\hline & & Controlled & Shofu & Fuji \\
\hline \multirow[t]{3}{*}{$1^{\text {st }}$ day } & Controlled & - & $197.1429 *$ & $112.4286^{*}$ \\
\hline & Shofu & - & - & $84.7143 *$ \\
\hline & Fuji & - & - & - \\
\hline \multirow[t]{3}{*}{$7^{\text {th }}$ day } & Controlled & - & $94.2857^{*}$ & $67.5714 *$ \\
\hline & Shofu & - & - & $26.7143^{*}$ \\
\hline & Fuji & - & - & - \\
\hline \multirow[t]{3}{*}{$14^{\text {th }}$ day } & Controlled & - & $56.7143^{*}$ & $32.2857 *$ \\
\hline & Shofu & - & - & $24.4286 *$ \\
\hline & Fuji & - & - & - \\
\hline
\end{tabular}

Note: * Significance

Table 4. The result of mean and deviation standard of the number of Streptococcus mutans colony on the observation of $1^{\text {st }}$ day, $7^{\text {th }}$ day, and $14^{\text {th }}$ day

\begin{tabular}{|c|c|c|c|c|c|c|}
\hline \multirow{3}{*}{ Samples } & \multicolumn{6}{|c|}{ The number of Streptococcus mutans colony (cfu/ml) } \\
\hline & \multicolumn{2}{|c|}{1} & \multicolumn{2}{|c|}{7} & \multicolumn{2}{|c|}{14} \\
\hline & Mean & DS & Mean & DS & Mean & DS \\
\hline Controlled & 451.71 & 10.70 & 475.28 & 9.69 & 491.28 & 12.29 \\
\hline Fuji & 273.14 & 5.08 & 356.00 & 7.07 & 385.42 & 5.56 \\
\hline Shofu & 128.71 & 7.38 & 243.00 & 5.91 & 351.57 & 6.29 \\
\hline
\end{tabular}


composition of the luting-type of glass ionomer cement Shofu had additional tannin-fluoride (HY-Agent), while the luting-type of glass ionomer cement Fuji had no such material. According to Ikeda et al., ${ }^{12}$ tannin-fluoride (HYAgent) was able to decelerate the growth of bacteria in saliva and tooth plaque. The presence of tannin-fluoride (HY-Agent) in large number would be very advantageous to eradicate the bacteria in the oral cavity and to assist controlling and preventing secondary caries. This was also confirmed by Yamaga et al. ${ }^{13}$ that tannin-fluoride (HYAgent) would result in penetrating fluoride into dentine more deeply so that it allowed to form binding with more stable apatite that reduced of caries resistance.

According to Subiyanto ${ }^{5}$ and Summit et al., ${ }^{8}$ the fluoride releasing from glass ionomer cement happened in the damaging phase caused by polyacrilate acid, it released ion $\mathrm{H}^{+}$from carboxyl cluster $(\mathrm{COOH})$ resulted in the separation of $\mathrm{F}^{-}$from the glass composition into diluted cement phase.

Anusavice $^{2}$ revealed that high concentration fluoride directly resulted in reducing the population of bacteria. The higher separation of fluoride caused by the lutingtype of glass ionomer cement made the $\mathrm{pH}$ of saliva reduced, while the concentration of saliva increased. On the other hand, the $\mathrm{pH}$ of bacterial intracellular liquid was higher than saliva, while the concentration of bacterial intracellular liquid was less than saliva. The difference of $\mathrm{pH}$ and concentration between saliva and bacterial intracellular liquid allowed fluoride to enter within the bacteria, affecting the carbohydrate metabolism leading to the change of cell structure. The fluoride released by glass ionomer cement influenced the growth of Streptococcus mutans by decelerating the activity of glicolotic enolase enzyme. The decrease of glicolotic enolase enzyme would reduce the number of phosphoenolpyruvate (PEP) that was necessary to transport glucose into the cells so that made glycolysis and synthesis of the intracellular glucose decelerated. Streptococcus mutans entered into the bacteria in the oral cavity that were sensitive toward the lower degree of fluoride in the lower $\mathrm{pH}$ environment. ${ }^{14}$ Normally, Streptococcus mutans live well in the $\mathrm{pH}$ of 7,4-7,6 and the optimum temperature for their growth is $37^{\circ} \mathrm{C}$, their growth reduces rapidly in the temperature of $40{ }^{\circ} \mathrm{C} .{ }^{15}$

Summit et $a l .^{8}$ stated that $\mathrm{pH}$ influenced the fluoride separation. It was assumed that the $\mathrm{pH}$ of the artificial saliva reduced because of the ion $\mathrm{H}^{+}$that was released by polyacrylate acid caused erosion the surface of glass ionomer cement. Kuhn and Wilson in the Seppä et al. ${ }^{16}$ revealed that the separation of glass ionomer cement fluoride was based on three reasons; surface wash-off, dissolution from cracks and fissures, and dissolution by solid-state diffusion from the bulk. The result of Forsten's

Table 5. The result of One-Way ANOVA test toward the number of Streptococcus mutans collony

\begin{tabular}{llrr}
\hline & & df & Sig. \\
\hline $1^{\text {st }}$ Day & Between Groups & 2 & .000 \\
& Within Groups & 18 & \\
& Total & 20 & .000 \\
$7^{\text {th }}$ Day & Between Groups & 2 & \\
& Within Groups & 18 & 0.00 \\
& Total & 20 & \\
& Between Groups & 2 & \\
& Within Groups & 18 & 20 \\
\end{tabular}

Table 6. The result of LSD test toward sreptococcus mutans colony

\begin{tabular}{|c|c|c|c|c|}
\hline & \multirow{2}{*}{ (I) } & \multicolumn{3}{|c|}{$(\mathrm{J})$} \\
\hline & & Controlled & Fuji & Shofu \\
\hline \multirow[t]{3}{*}{$1^{\text {st }}$ Day } & Controlled & - & $178.5714 *$ & $323.0000 *$ \\
\hline & Fuji & - & - & $144.4286^{*}$ \\
\hline & Shofu & - & - & - \\
\hline \multirow[t]{3}{*}{$7^{\text {th }}$ Day } & Controlled & - & $119.2857 *$ & $232.2857^{*}$ \\
\hline & Fuji & - & - & $113.0000^{*}$ \\
\hline & Shofu & - & - & - \\
\hline \multirow[t]{3}{*}{$14^{\text {th }}$ Day } & Controlled & - & $105.8571 *$ & $139.7143^{*}$ \\
\hline & Fuji & - & - & $33.8571^{*}$ \\
\hline & Shofu & - & - & - \\
\hline
\end{tabular}

Note: * Significance 
research in Subiyanto ${ }^{5}$ showed that lower $\mathrm{pH}$ released more ion fluoride. In the $\mathrm{pH}$ of 6,1 ion fluoride released in the $7^{\text {th }}$ day was $2,3 \mathrm{ppm}$, while in the $\mathrm{pH}$ of 5.0 the ion fluoride separation was $4,1 \mathrm{ppm}$.

In the observation of $1^{\text {st }}$ day, it showed the least number of bacterial colony compared to the $7^{\text {th }}$ day and $14^{\text {th }}$ day, it could be assumed that fluoride is mostly released in the $1^{\text {st }}$ day, and then decreased regularly. Perin et al. cit. Summit et al., ${ }^{8}$ Carey et al. ${ }^{17}$ and Weidlich et al. ${ }^{18}$ reported that in the measurement of separation of glass ionomer cement fluoride, the greatest separation occurred on the first day, decreased rapidly on the second day, and reduced regularly more than 3 weeks to the lower level on the long-term separation. Summit et al. ${ }^{8}$ said that no glass ionomer cement was able to retain its acidity more than 48 hours. The material that released ion would also release the other fluoride and ion with decreased degree in line with time so that the direct bactericidal effect from the fluoride separation was limited. $\mathrm{Craig}^{7}$ research stated that there was no improvement on the number of bacteria during 56 days after crown cementation using glass ionomer cement. After 1 year, however, the glass ionomer cement still released fluoride with the concentration of $0.05 \mathrm{ppm}$ each day.

The separation of fluoride from a restoration material was influenced by intrinsic and extrinsic factors. The intrinsic factor was influenced by the comparison of powder and fluid, mixing time, temperature, specimen shape, surface coating and polishing. The extrinsic factor was related to the mediator $(\mathrm{pH})$, temperature, composition, immersion fluid volume and the frequency of immersion replacement. ${ }^{19}$

Granfield et al. cit. Summit et al. ${ }^{8}$ reported that fluoride separation was influenced by the shape of specimen. The specimen with more extended surface would release more fluoride. They also reported that $\mathrm{pH}$ influenced the fluoride separation. Smith and Ruse in Davidson and Mjör ${ }^{3}$ also reported that there was $\mathrm{pH}$ change during setting (initial acidity). The low $\mathrm{pH}$ in the initial mixing of powder and fluid was $\mathrm{pH} 2$ in $1-5$ minutes mixing, $\mathrm{pH} 3$ after 10 minutes mixing. This low $\mathrm{pH}$ of glass ionomer cement was unable to retain over 48 hours after application. This was influenced by the separation of fluoride from glass ionomer cement which was the process of solvent selective decomposition from the artificial saliva so that the number of fluoride separation was greater and the $\mathrm{pH}$ of artificial saliva tended to more acidity.

Based on the result of the research, it was concluded that the luting-type of glass ionomer cement possessed antibacterial force toward Streptococcus mutans and Lactobacillus sp. The luting-type of glass ionomer cement of Shofu had greater antibacterial force than Fuji and the controlled-group. As consideration to choose cementation material in clinic, it is necessary to conduct further research on the various brands of luting-type of glass ionomer cement and other adhesive materials which are not classified into glass ionomer cement.

\section{ACKNOWLEDGEMENT}

Thank you very much to Trisia Fajarini and Didit Hidayat for your helping.

\section{REFERENCES}

1. Ford PTR. Restorasi gigi. $2^{\text {nd }}$ ed. Sumawinata N, editor. The restoration of teeth. Jakarta: EGC; 1993. p. 10, 117, 118.

2. Anusavice KJ, Phillips. Buku ajar ilmu bahan kedokteran gigi. $10^{\text {th }}$ ed. Budiman JA, Purwoko S. Philip's Science of dental materials. Jakarta: EGC; 2003. p. 447, 471.

3. Davidson CL, Mjör IA. Advances in glass ionomer cements. Germany: Quintinessence Publishing Co Inc; 1999. p. 149, 155.

4. Van Noort R. Introduction to dental materials. $2^{\text {nd }}$ ed. USA: MosbyYear Book, Inc; 2002. p.124.

5. Subiyanto A. Daya antibakteri semen gelas ionomer tipe perekat dan tumpatan terhadap Streptococcus mutans. Majalah Kedokteran Gigi (Dental Journal) 2002; 35(93):111-3.

6. Baum, Lloyd, Phillips, Ralph W, Lund, Melvin R. Buku ajar ilmu konservasi gigi. $3^{\text {rd }}$ ed. Tarigan R, editor. Textbook of operative dentistry. Jakarta: EGC; 1994. p. 669.

7. Craig RG. Restorative dental materials. $10^{\text {th }}$ ed. USA: Mosby-Year Book, Inc; 1996. p. 194

8. Summit JB, et al. Fundamentals of operative dentistry. A contemporary approach. $2^{\text {nd }}$ ed. Quintessence Publishing Co, Inc; 2001. p. 379, 380, 382.

9. Budi AT. Pengaruh antibakteri dari bahan restorasi semen gelas ionomer dengan teknik ART terhadap Streptokokus mutans. Majalah Kedokteran Gigi (Dental Journal) 2001; 34(3a):154-56.

10. Kusumaningsih T. Pengujian antibodi saliva terhadap Streptococcus mutans 1 dan Streptococcus mutans 3 pada karies aktif dan karies terawat anak umur 4, 6 tahun di TK. Ki Hajar Dewantoro. Majalah Kedokteran Gigi (Dental Journal) 1992; 25(1):172.

11. Alcamo EJ. Laboratory fundamentals of microbiology. New York: Addison-Wesley Publishing; 1983. p.73.

12. Ikeda S, Igarashi T, Goto N. Miyazaki T. Antibacterial effect of glass ionomer cement combined with tannin-fluoride (HY-agent) on oral bacterial. J Dent Mate 2000; 19(5):456-63. Abstract. [on line] Available at: http://www.soc.nii.ac.jp/jsdmd/2000/19-5je.html. Accessed June 21, 2006.

13. Yamaga M, Koide T, Hieda T. Fluorine uptake and cristallinity of dentin treated with glass ionomer cement containing tannin-fluoride preparation. Dent Mater J 1994 Jun; 13(1):89-102. Abstract. [on line] Available at: http://www.ncbi.nlm.nih.gov. Accessed July 3, 2006.

14. Marsh, Martin. Oral biology. Cornwell Great Britain. MPG Books Ltd; 1999. p. 96-97.

15. Syahrurachman A, et al. Buku ajar mikrobiologi kedokteran. Revised edition. Jakarta: Binarupa Aksara; 1993. p. 112

16. Seppä L, Forss H, Øgaard B. The effect of fluoride application on fluoride release and the antibacterial action of glass ionomers. J Dent Res 1993 September; 72(9):1310-4. [serial on line] Available at: http://www.jdr.iadrjournals.org. Accessed August 30, 2006.

17. Carey CM, Spencer M, Gove RJ, Eichmiller FC. Fluoride release from a resin-modified glass-ionomer cement in a continuous-flow system: Effect of pH. J Dent Res 2003; 82(10):829-32. International and American Associations for Dental Research. [serial on line] Available at: http://jdr.iadrjournals.org/cgi/content/full. Accessed June 22, 2006.

18. Weidlich P, Miranda LA, Maltz M, Samuel SMW. Fluoride release and uptake from glass ionomer cements and composite resins. Braz Dent J 2000; 11(2):89-96. [serial on line] Available at: http://forp. usp.br/bdj.htm. Accessed May 3, 2006.

19. Nuraini P. Pelepasan fluorida maksimal semen gelas ionomer. Majalah Kedokteran Gigi (Dental Journal) 2001 August; 34 (3a):545-7. 